\title{
1. A template for the world: British Columbia's carbon tax shift
}

\author{
Thomas F. Pedersen and Stewart Elgie
}

\section{INTRODUCTION}

Throughout the nineteenth and most of the twentieth centuries, the Mountain Pine Bark Beetle, a relatively innocuous five millimetre-long member of the weevil family, was known to attack and kill a limited number of mature pine trees annually in the forests of British Columbia (BC). That changed in the late 1990s when the beetle launched an assault on British Columbia's pine forests that by the mid-2000s had become 'the most severe bark beetle infestation in recorded North American history."

By 2012, approximately one-third of British Columbia's 55 million hectares of forest had been afflicted by the pine bark beetle. Over 50 per cent of the stock of commercially valuable pine was dead, representing some 710 million $\mathrm{m}^{3}$ of wood. The harvest and processing of a cubic metre of timber in BC yields some $\$ 110-\$ 130$ to provincial GDP; ${ }^{2}$ hence, even though it was possible to harvest some of the dead pine trees, the net economic impact of the pine bark beetle has been severe.

As concern about the economic, social and environmental implications of the beetle epidemic grew, the Government of $\mathrm{BC}$ accepted that the beetle outbreak had been facilitated by warming associated with greenhouse gas emissions. The strong-willed Premier of the day, Gordon Campbell, decided that $\mathrm{BC}$ had to take steps to contribute to climate change mitigation by reducing fossil fuel use. He heeded economists who advised that by assigning a slowly rising cost to emissions demand for fossil fuels would decline and the economy would have time to adjust without serious dislocation. Campbell and his government wasted no time; BC's Finance Minister announced in her February 2008 budget that a carbon tax was to be put in place, and five months later it took effect: on 1 July 2008, British Columbia became the first jurisdiction in North America to impose a legislated, progressively increasing, broad-spectrum, revenue-neutral carbon emissions tax, thanks in part to the activities of a half-centimetre-long 
bark beetle that was busily carving a swath of destruction through the pine forests of BC's interior.

This chapter describes the structure of the tax, its apparent positive impact on reducing the consumption of fossil fuels in BC, and implications for emissions mitigations policy that we believe warrant serious consideration by other national and sub-national jurisdictions.

\section{STRUCTURE AND APPLICATION OF THE TAX}

Seven key elements define the structure and application of the tax:

1. The tax is comprehensive. It is applied to all greenhouse gas emissions generated by combustion of fossil fuels purchased in the Province, with the exceptions of aviation fuel used for out-of-province flights and fuel used in interjurisdictional cruise ships, since most of the combustion of such fuels would occur outside BC's borders.

2. Tax rates were scheduled for five years. The initial rate established in 2008 was relatively modest at $\$ 10$ (CAD) per tonne of $\mathrm{CO}_{2}$ equivalent $\left(\mathrm{CO}_{2} \mathrm{e}\right)$ emitted. Importantly, the schedule required the tax to increase by $\$ 5$ per tonne on 1 July of each of the next four years, to $\$ 30 / t \mathrm{CO}_{2} \mathrm{e} /$ year on 1 July 2012 . It has been fixed at that rate since. The rationale for the slow upward ramp in the tariff was that it would encourage gradual adjustment in fossil fuel use both by industry and private consumers while minimizing economic dislocation. \$5/t/year equates to a 1.1 cent annual increase in the cost of a litre of regular gasoline, a rate of increase that was judged to be acceptable to average consumers.

3. Higher carbon fuels are taxed at a higher rate, as shown in Table 1.1. This design feature ensures that relative externality costs of each fuel are fairly assessed.

4. The tax was mandated to be revenue neutral. Every penny of revenue was required by law to be returned to the residents of British Columbia through reductions in personal, small business and corporate income taxes and some direct fiscal transfers. Thus, the carbon tax in reality represented a tax shift, not new revenue. This design element: (a) strongly encouraged conservation - those individuals or companies that reduced fossil fuel consumption benefitted with a lower overall tax burden, since income taxes were reduced regardless; (b) erased any opportunity to describe the initiative as a 'tax grab'; and (c) minimized or avoided an overall adverse effect on the economy, by lowering other taxes. 
Table 1.1 British Columbia carbon tax rates for selected fuels as of 1 July 2008 and as of 1 July 2012, following four years of successive increases $^{3}$

\begin{tabular}{llcc}
\hline Fuel & Units & 2008 Tax Rate & 2012 Tax Rate \\
\hline Gasoline & $\varnothing /$ litre & 2.41 & 6.67 \\
Diesel $^{4}$ & $\varnothing /$ litre & 2.76 & 7.67 \\
Natural gas & c/cubic metre & 1.90 & 5.70 \\
Propane & $\notin /$ litre & 1.53 & 4.62 \\
Coal, high heat value & \$/tonne & 20.79 & 62.31 \\
Coal, low heat value & \$/tonne & 17.72 & 53.31 \\
\hline
\end{tabular}

Note: The 2008 and 2012 rates are calculated on the basis of $\$ 10$ and $\$ 30$ (CAD) per tonne of $\mathrm{CO}_{2}$ equivalent released via combustion, respectively.

5. Social equity was accommodated via two provisions: (a) on 1 January 2008, six months before the carbon tax took effect, personal income tax rates in $\mathrm{BC}$ were reduced by 5 per cent on each of the lowest two tiers of BC's progressive income tax rate schedule. As a result, $\mathrm{BC}$ now has the lowest personal income taxes in Canada for anyone earning up to $\$ 122,000$ in net taxable income; (b) a 'Low Income Climate Action Tax Credit' ${ }^{5}$ was established to offset the impact of the carbon tax. The credit is non-taxable and paid quarterly, with the current annual maximum being $\$ 115.50$ per adult and $\$ 34.50$ per child ( $\$ 115.50$ for the first child in a single parent family). The credit diminishes by 2 per cent of net annual family income over a current threshold of $\$ 37,589$. The threshold is adjusted upward annually to allow for inflation.

6. General corporate income tax rates were reduced from 12 per cent to 11 per cent on 1 July 2008, to 10.5 per cent on 1 January 2010 , and to 10 per cent on 1 January $2011^{6}$ taking them to a level amongst the lowest in the OECD countries. The Small Business Corporate Tax rate, which applied to companies with annual business income up to $\$ 400,000$ was reduced from 3.5 to 2.5 per cent on 1 December 2008 , a net reduction of nearly 29 per cent.

7. Bureaucratic requirements were minimized. On all fossil fuels other than natural gas, the carbon tax built upon existing fuel tax collection mechanisms that require tax to be collected and remitted at the wholesale level. ${ }^{7}$ For natural gas, the retailer collects and remits the tax. ${ }^{8}$ This approach greatly minimizes administrative and compliance costs. 


\section{APPARENT IMPACT OF THE CARBON TAX ON EMISSIONS}

\section{Methods}

Changes in fossil fuel use since 1 July 2008 were assessed using fuel volume data from Statistics Canada through December 2013. Annual results are computed for the period 1 July to 30 June, to isolate better the effects of annual increases in the carbon tax rate that took effect on 1 July of each year. The data are thus reported for hybrid years (for example, 2008-2009). BC consumption patterns are compared with the rest of Canada, which helps to factor out any effects resulting from GDP changes or other common impacts like the recession of 2008-2009. Population change influences are removed by reporting the data on a per capita basis.

Volumetric fuel use figures were taken from Statistics Canada's dataset 'Supply and Disposition of Refined Petroleum Products (CANSIM 134-004)'. Population data came from CANSIM 051-0001 and GDP figures from CANSIM 379-0030. Note that GDP results are given by calendar year, rather than 1 July to 30 June year, due to constraints in data availability.

Inclusion of natural gas in the analysis required combining two Statistics Canada datasets (Petroleum Products, and Sales of Natural Gas / CANSIM 129-0003), and converting all fuel figures from volume to energy (terajoules) to enable comparability (since natural gas has very high volumes per unit of energy compared with other fuels).

A few values were missing for certain petroleum products for select months from March to June 2013, due to recent changes in data sharing agreements between Statistics Canada and particular companies. To fill the gaps, values for the missing months were estimated using standard methods in consultation with Statistics Canada, and total fuel sales for 2012-2013 were estimated using a Kalman filter algorithm. ${ }^{9}$ Given that data were missing for only a few months of one year, we have confidence that the final results are accurate within a very small margin of error. All data are available from Dr Elgie upon request.

\section{Results}

Since the midpoint of 2008 when the carbon tax was first imposed, per capita consumption of fossil fuels in British Columbia has fallen by just over 16 per cent (Table 1.2) in absolute terms, and by just over 19 per cent relative to the rest of Canada $(\mathrm{RoC})$. The contrast between $\mathrm{BC}$ and the 
Table 1.2 Per cent changes in per capita consumption of petroleum products (gasoline, diesel, fuel oil and propane) in British Columbia and the rest of Canada between 1 July 2007 and 30 June 2013

\begin{tabular}{lcccccc}
\hline & $2007 / 08-$ & $2008 / 09-$ & $2009 / 10-$ & $2010 / 11-$ & $2011 / 12-$ & $2007 / 08-$ \\
& $2008 / 09$ & $2009 / 10$ & $2010 / 11$ & $2011 / 12$ & $2012 / 13$ & $2012 / 13$ \\
\hline British Columbia & -3.5 & -6.7 & -1.3 & -6.2 & 0.2 & -16.1 \\
Rest of Canada & -2.5 & -1.5 & 6.8 & -1.7 & 1.7 & 3.0 \\
Difference & -1.0 & -5.2 & -8.1 & -4.5 & -1.5 & -19.1 \\
\hline
\end{tabular}

Note: With the exception of the final column, the data are reported as year-to-year differences between 12-month July through June averages.

RoC is stark. BC outperformed the RoC every year since the carbon tax came in, in terms of changes in per capita fuel use, including between 2011/12 and 2012/13, which includes the 12 months after the carbon tax was frozen.

This analysis begs the key question: can the clear decline in both absolute and relative fossil fuel consumption in BC since mid-2008 be unequivocally attributed to the carbon tax? The simple answer is no, attribution is not unequivocal. But a closer examination of the data and of other plausible drivers suggests strongly that the tax is indeed responsible for at least a large portion of BC's gains.

The tax was introduced just as the severe global recession of 2008-2009 struck the world economy. British Columbia was hit hard by the recession: provincial GDP fell from an average annual growth rate of 3.49 per cent over the 2002-2007 period to 0.97 per cent in 2008 and -2.58 per cent in 2009 , before recovering in 2010 to +3.3 per cent. ${ }^{10}$ Undoubtedly, the decline in industrial production and demand for the Province's raw materials had a negative impact on fuel use during the depth of the recession. But other provinces went through a similar downturn and comparing their fuel consumption data with those in $\mathrm{BC}$ helps to normalize out the impact of the recession while casting the spotlight on the possible influence of the carbon tax. The difference data in Table 1.2 compare the change in annual per capita consumption of fossil fuel products in British Columbia since 2007/08 with the same variable aggregated over the RoC. In two of the three post-recession years, per capita fuel consumption increased in the RoC while it declined in BC. Over the course of the five years of data tabulated in Table 1.2, per capita fossil fuel use in BC fell by just over 19 per cent relative to the rest of the country. The contrast is dramatic, and 
signals clearly that the recession cannot be blamed for the decline in fuel consumption in $\mathrm{BC}$ relative to the rest of Canada in the years following the introduction of the tax.

Perhaps other influences exclusive of the carbon tax can explain the declining fuel use in British Columbia. Two such candidates are: (a) access to cheaper gas in Washington State, recognizing that a significant proportion of $\mathrm{BC}$ residents live within $50 \mathrm{~km}$ of the border; and (b) continuation of an independent downward trend that began before the carbon tax was introduced. We consider these in turn.

It is a fact that traffic between $\mathrm{BC}$ and Washington has increased substantially since 2008 , a cross-border response that most likely reflects the very high value of the Canadian dollar from 2009 to 2013 and the lower cost of most consumer goods in the United States. And while shopping south of the border, it is quite likely that many BC residents filled up the gas tanks in their cars. Two independent researchers, ${ }^{11}$ one in Canada and one in the US, have recently estimated that this could account for only a 1 to 2 per cent drop in fuel purchases in $\mathrm{BC}$, a small fraction of the $\sim 16$ per cent overall decline witnessed since 2008 (Table 1.2). Moreover there has been a decline in use in recent years of every type of fuel covered by BC's tax policy, relative to the rest of Canada (Figure 1.1), and with the exceptions of gasoline and diesel, these fuels are not subject to cross-border shopping. We conclude that cross-border purchases can explain only a small fraction of BC's dramatic drop in fuel use since the advent of the carbon tax.

A second possible explanation for BC's declining fossil-fuel consumption could be that it is the continuation of a pre-existing trend, which if true, would suggest that the carbon tax was less effective or even ineffective. To test this, we looked at the sales data for all fuels subject to the tax back to 2000 (Figure 1.2). British Columbians did use less fuel per capita relative to the rest of Canada prior to 1 July 2008, in part because BC enjoys an abundance of carbon-free hydropower. But as Figure 1.2 illustrates, per capita fuel use in BC was actually rising slightly (by $\sim 1$ per cent per year) compared with the rest of Canada between 2000 and 2008. Following imposition of the carbon tax on 1 July 2008, fuel use in BC fell by $\sim 4$ per cent per year compared with the rest of Canada. This beforeand-after shift in the data is clear, and argues against the possibility that the decline in fuel consumption post-tax was simply a continuation of a pre-existing trend.

\section{Behavioural Implications}

Although the data clearly show that per capita fossil-fuel consumption has declined in recent years as the carbon tax escalated, we cannot 


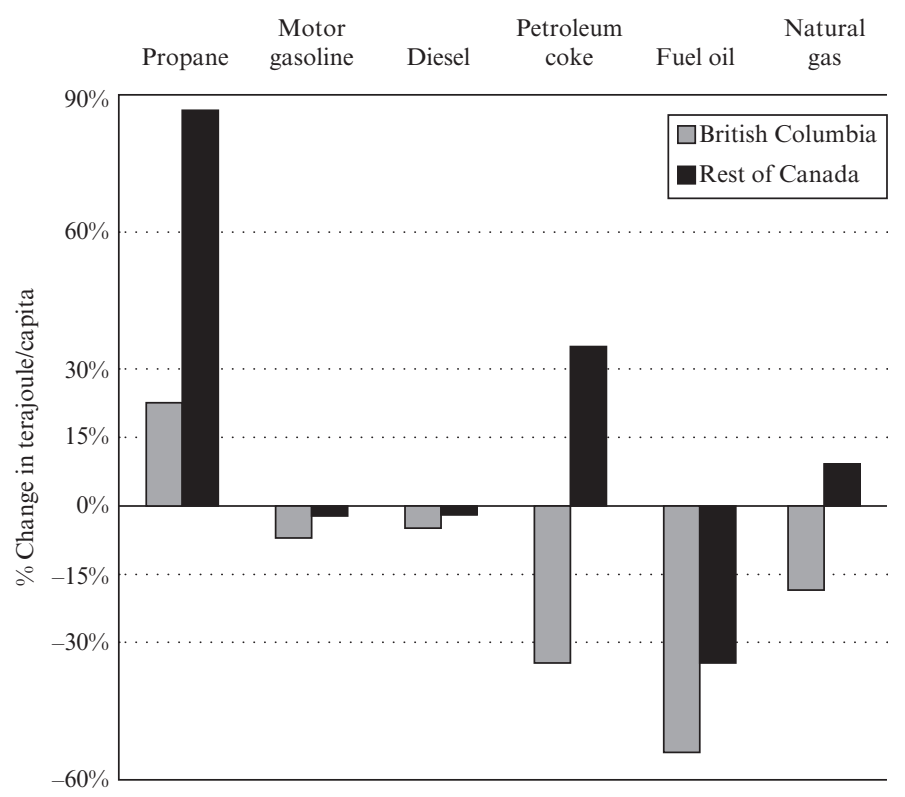

Note: The steep decline in sales of fuel oil is attributed to refineries in $\mathrm{BC}$ switching production from 'heavy fuel oil' to ultra-low sulfur diesel in response to new marine shipping and domestic transportation regulations on sulfur content of fuels.

Source: Figure produced by Sustainable Prosperity, University of Ottawa.

Figure 1.1 Percentage change in sales of specific fuels in British

Columbia, reported as terajoules per capita over the six years beginning 1 July 2007

conclude with 100 per cent confidence that the tax on its own is the reason. Correlation is not enough. BC introduced other initiatives in 2008 designed to reduce emissions, including for example the introduction of a Renewable and Low Carbon Fuel Standard (RLCFS). ${ }^{12}$ But while the RLCFS can contribute to an emissions decline, given that it purposely reduces the fossil carbon content of fuels, it does not send a price signal that would reduce fuel-volume demand. The carbon tax does send such a signal, however, and its impact is borne out by fuel sales data. Statistics Canada data show that per capita sales of motor gasoline in British Columbia fell from an average of $1.121 \mathrm{~m}^{3}$ in the 2000-2007 time span to $1.037 \mathrm{~m}^{3}$ over the 2008-2013 period, a decline of 7.5 per cent. Over the same two time periods, the rest of Canada witnessed an increase in sales of motor gasoline from 1.294 to $1.316 \mathrm{~m}^{3} /$ per capita $(+1.7$ per cent). We suggest that the carbon tax 


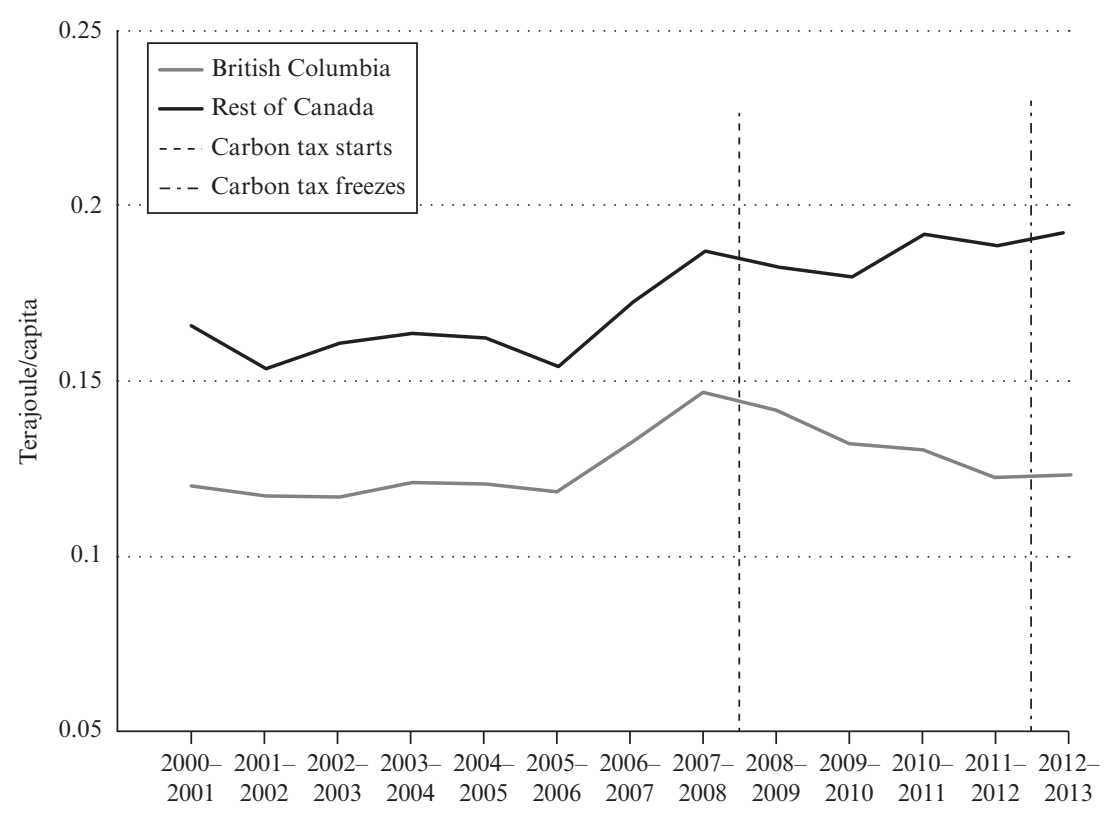

Note: The vertical dashed line indicates the date of imposition of the carbon tax while the vertical dashed/dotted line marks the beginning of the tax freeze plateau (the tax has been fixed at $\$ 30 /$ tonne $\mathrm{CO}_{2}$ e since 1 July 2012).

Source: Figure produced by Sustainable Prosperity, University of Ottawa.

\section{Figure 1.2 Aggregate annual per capita fuel sales in BC (grey) and the rest of Canada (black) from 1 July 2000 to 30 June 2013}

contributed to this contrast. BC also introduced in 2008 a requirement for all provincial government institutions to become carbon neutral by 2012 . That requirement was met in 2011, in small part through energy conservation measures and in large part with the purchase of offsets. ${ }^{13}$ Thus, while it may have attuned the population to the need to take climate action, it had little actual impact on fossil fuel sales.

While we can reasonably assume that the carbon tax played a significant role in encouraging lower fuel use, quantifying such an impact is difficult. The tax may, for example, have stimulated an adoption rate for hybridelectric vehicles that is more than twice the average for Canada - between 2007 and 2010, hybrid sales in BC grew by 31 per cent per year, faster than elsewhere in the country. ${ }^{14}$ But hybrid vehicles sales still comprise less than 2 per cent of all vehicles sold in $\mathrm{BC}$ so their aggregate impact on fuel economy is judged to be small. ${ }^{15}$ Public transit ridership in $\mathrm{BC}$ grew 
by nearly 12 per cent between $2007 / 08$ and $2011 / 12^{16}$ and while it is tempting to point to an influence of the carbon tax in promoting such growth, transit service was also expanded during this period and that confounds attribution of increased ridership to the tax. Moreover improvements to building codes, including better insulation standards, and building retrofits supported with provincial government rebates have also reduced consumption of fossil fuels used for space heating in BC. The presence of a carbon tax makes such improvements more attractive but it is not possible to quantify its proportionate impact relative to other policies like retrofit rebates.

Better quantification is possible, however, using an econometric approach to explore the supposition that tax-driven price changes generate distinct responses in demand when compared with equivalent market-based price movements. Nicholas Rivers and Brandon Schaufele at the University of Ottawa recently conducted detailed econometric analyses in examining this hypothesis, and noted that, 'the BC carbon tax generated demand response that is 4.9 times larger than is attributable to an equivalent change in the carbon tax-exclusive price'. ${ }^{17}$ This differential behavioural response is judged by these authors to be causal and is attributed to the high visibility of the tax, the 'relief of guilt' associated with paying an 'environmental tax', and possibly to resentment of free-ridership, wherein since every fuel consumer pays the carbon tax, environmental responsibility practiced by one, for example by driving less, cannot be subverted by another who cares less and drives more when congestion eases. Of these options, the high visibility of the tax is assumed here to have been of critical importance.

The media in British Columbia played a direct role in reinforcing that visibility. The imposition of the tax on 1 July 2008 coincided with a record high world price for oil, which peaked at about US $\$ 132$ per barrel ${ }^{18}$ at almost exactly the same time. The quantum of the carbon tax added to the gasoline price was tiny, just $2.4 \mathrm{c} / \mathrm{L}$ for regular gasoline in British Columbia. In Victoria, BC, for example, the price rose from $\$ 1.469 / \mathrm{L}$ on 30 June to $\$ 1.494 / \mathrm{L}$ at 00:00 hours on $1 \mathrm{July}$, after having risen substantially and progressively by about $40 \mathrm{c} / \mathrm{L}$ over the previous six months. That halfyear history did not faze the headline writer in the local Times Colonist newspaper, who wrote in bold print on the front page of the 2 July 2008 edition $^{19}$ : 'Gas prices push $\$ 1.50$ as carbon tax kicks in'. Similar headlines appeared repeatedly in subsequent years, near or on the anniversary date. On 1 July 2010, the CBC posted, ${ }^{20}$ 'BC carbon tax jumps more than 1 cent'. (That headline, of course, was inaccurate - the tax actually rose $\$ 5 / \mathrm{t} / \mathrm{CO}_{2} \mathrm{e}$, which translates to a little over $1 \propto / \mathrm{L}$ on gasoline, but regardless, it strengthened the public message.) On 1 July 2011, the Canadian Press echoed the theme ${ }^{21}$ with a story entitled, 'Carbon tax bumps up BC 
fuels prices', and exactly one year later Canada's 'national newspaper', the Globe and Mail, added yet another reinforcing headline:22 'BC to raise carbon tax, price of gasoline on July 1'. Over the course of five years, the British Columbia public repeatedly heard at the end of June or beginning of July that the price of fuels went up, and they were repeatedly signalled that this trend was to continue, thanks to the carbon tax. That message sunk in, and we believe - but cannot prove with absolute confidence - that it was instrumental in shifting behaviour at the individual level towards lowering fossil fuel consumption.

\section{THE REVENUE NEUTRALITY ISSUE}

The evident success of the tax has introduced an unanticipated irony: revenue neutrality was never reached. Personal and corporate income tax cuts have exceeded carbon tax revenue in every year since the introduction of the tariff in 2008. In 2012-2013 for example, the tax generated an estimated $\$ 1120$ million in revenue while the personal and corporate income tax cuts accounted for an estimated decline in revenue to the treasury of $\$ 1380$ million, a shortfall of $\$ 260$ million relative to neutrality. Rather than the tax being a net imposition on the taxpayers of British Columbia, it has instead put nearly $\$ 800$ million net into their pockets since 2008 . The reason for this disparity is simple: the decline in the consumption of fossil fuels since the tax was introduced exceeded that anticipated by the economic models used in 2007 to forecast revenue from the tax. Those forecasts were used to determine the scale of income tax reductions put in place in 2008. From the revenue neutrality perspective, therefore, the tax appears to have been too successful.

\section{RELATIVE ECONOMIC PERFORMANCE IN BRITISH COLUMBIA}

Some commentators have suggested that carbon taxes harm economic growth. While this must be true at some taxation level, there is no indication that BC's tax has had any overall negative economic impact since inception in 2008. Indeed, British Columbia's GDP growth has kept pace with or slightly exceeded that of Canada as a whole since 2006/07 despite constraints including lagging demand for BC lumber by the sluggish US housing market. ${ }^{23}$ The carbon tax is only a tiny component of the overall economy, so one would not expect it to have a significant effect, especially given its revenue neutrality. 
The lack of negative economic impact extends to the sectoral level. Rivers and Schaufele (2014) have recently shown for example that BC's carbon tax has had no discernible impact, positive or negative, on the export of agricultural products from BC. ${ }^{24}$ When considered collectively, the data now available at both the macro (pan-Canadian) and provincial sectoral levels confirm that, as designed and applied, British Columbia's now permanent carbon-emissions taxation program has not produced economic harm. In fact, the carbon tax may well have been a factor in stimulating significant growth in recent years in the energy-related high technology sector in the Province. Between 2009 and 2011, for example, revenue generated by the clean technology sector in $\mathrm{BC}$ grew 17 per cent ${ }^{25}$ and the sector remains a locus of significant expansion.

\section{CONCLUSION}

By all yardsticks, BC's carbon tax has been a success. Its primary objective has been achieved: fossil fuel consumption on a per capita basis has fallen substantially, and interim emissions reductions targets set by legislation have been met, ${ }^{26,27}$ albeit in part through the purchase of offsets. Some 70 per cent of British Columbians now support the tax, and a majority would like to see it increase ${ }^{28,29}$ but with the new revenue being directed towards green initiatives like home-energy-efficiency retrofits rather than further corporate tax reductions. And there has been little negative political backlash to the tax; indeed the centre-right BC Liberal Party that introduced the tax in 2008 was re-elected in 2009 to a third successive term in part because the carbon tax attracted the environmental vote. ${ }^{30}$

BC's experience shows that a carefully thought-through tax shift that penalizes pollution while rewarding conservation and improving environmental outcomes can be a winner. Indeed, the tax has received much attention on the international stage. Professor Paul Ekins, head of the Green Fiscal Commission of the United Kingdom, for example, has praised the $\mathrm{BC}$ carbon tax as being 'among the best designed measures of its kind in the world'.$^{31}$ The evidence presented here fully supports his observation.

\section{NOTES}

1. BC Ministry of Forests, Lands and Natural Resource Operations (2012), 'A History of the Battle Against the Mountain Pine Beetle: 2000 to 2012', www.for.gov.bc.ca/hfp/ mountain_pine_beetle/Pine $\% 20$ Beetle $\% 20$ Response $\% 20$ Brief $\% 20$ History $\% 20 \mathrm{May} \% 20$ 23\%202012.pdf, accessed 26 July 2014.

2. BC Ministry of Forests, Mines and Lands (2010), 'The State of British Columbia's 
Forests, 3rd edn', www.for.gov.bc.ca/hfp/sof/index.htm\#2010_report, accessed 28 July 2014.

3. BC Ministry of Finance (2014), 'Tax Rates on Fuels', www.sbr.gov.bc.ca/documents_ library/bulletins/mft-ct_005.pdf, accessed 25 July 2014.

4. The carbon tax rate for gasoline and diesel is lower than would be expected for pure gasoline and diesel because the fuels contain some ethanol and biodiesel as required by renewable fuels legislation. These non-fossil components are factored into the rate charged per litre.

5. Government of BC (2014), 'Low Income Climate Action Tax Credit', www2.gov.bc.ca/ gov/topic.page?id=E9258ADE1AE3423080A1B2674F4EAABD, accessed 22 July 2014.

6. Government of BC (2014), 'Tax Rates and Business Limits', www2.gov.bc.ca/gov/topic. page $?$ id =68E5DBC15D4F458CB2783F35CFABB19C, accessed 22 July 2014.

7. BC Ministry of Finance (2014), 'Fuel Sellers', www.sbr.gov.bc.ca/documents_library/ bulletins/mft-ct_001.pdf, accessed 22 July 2014.

8. BC Ministry of Finance (2014), 'Natural Gas and Biomethane Sellers', www.sbr.gov. bc.ca/documents_library/bulletins/ct_001.pdf, accessed 22 July 2014.

9. McLeod, A.I., H. Yu and E. Mahdi (2011), 'Time Series Analysis with R', Handbook of Statistics, 30, Elsevier.

10. BC Stats (2014), '1997-2013 Chained 2007\$', www.bcstats.gov.bc.ca/StatisticsBySubject/ Economy/EconomicAccounts.aspx, accessed 23 July 2014.

11. Skuce, Andy (2014), http://critical-angle.net/2013/08/18/the-effect-of-cross-bordershopping-on-bc-fuel-consumption-estimates/, and Bauman, Yoram (2014), http://daily. sightline.org/2014/05/21/the-canadians-are-coming/, both accessed 24 July 2014.

12. Government of BC (2008), 'Bill 16 - Greenhouse Gas Reduction Act', www.leg. bc.ca/38th4th/3rd_read/gov16-3.htm, accessed 24 July 2014.

13. Government of BC (2012), www.livesmartbc.ca/attachments/carbon_neutral_action_ reports/CarbonNeutralBC-transformingBCpublicsector.pdf, accessed 24 July 2014.

14. Littlejohn, Dale (2012), 'A Primer on the Transition to Electric Vehicles in Vancouver', www.communityenergy.bc.ca/sites/default/files/Road $\% 20$ to $\% 20$ Zero-Metro $\% 20$ Vancouver\%20EV\%20Primer\%202012-02-09.pdf, accessed 24 July 2014.

15. Chandra, A., S. Gulati and M. Kandlikar (2010), 'Green Drivers or Free Riders? An Analysis of Tax Rebates for Hybrid Vehicles', Journal of Environmental Economics and Management, 60(2), 78-93.

16. Office of the Auditor General of BC, Summary Report 8 (2012), www.OAGBC\%20 Dec\%20Summary\%20Report2012.pdf, accessed 24 July 2014.

17. Rivers, N. and B. Schaufele (2013), 'Salience of Carbon Taxes in the Gasoline Market', http:/dx.doi.org/10.2139/ssrn.2131468, accessed 25 July 2014.

18. Index Mundi (2014), www.indexmundi.com/commodities/?commodity=crudeoil\&months $=240$, accessed 26 July 2014 .

19. Victoria Times Colonist (2008), www.canada.com/victoriatimescolonist/story. html?id=9d7dfec8-9174-48c9-a766-1af4274a64cd, accessed 28 July 2014.

20. CBC News (2010), www.cbc.ca/news/canada/british-columbia/b-c-carbon-tax-jumpsmore-than-1-cent-1.915792, accessed 28 July 2014.

21. CBC News (2011), www.cbc.ca/news/canada/british-columbia/carbon-tax-bumps-up-bc-fuels-prices-1.1009204, accessed 28 July 2014.

22. Globe and Mail (2012), www.theglobeandmail.com/report-on-business/industrynews/energy-and-resources/bc-to-raise-carbon-tax-price-of-gasoline-july-1/ article4374532/\#dashboard/follows/, accessed 28 July 2014.

23. Service Canada (2013), 'Environmental Scan, British Columbia', www.esdc.gc.ca/eng/ jobs/lmi/publications/e-scan/bc/bc-e-scan-201303.pdf, accessed 28 July 2014.

24. Rivers, N. and B. Schaufele (2014), 'The Effect of British Columbia's Carbon Tax on Agricultural Trade', www.pics.uvic.ca/sites/default/files/uploads/ publications/Carbon $\% 20$ Tax $\% 20$ on $\% 20$ Agricultural $\% 20$ Trade.pdf, accessed 28 July 2014. 
25. Bennett, N. (2012), http://www.biv.com/article/2012/11/bc-companies-finding-thegreen-in-clean/, accessed 12 November 2014.

26. Government of BC (2012), www.env.gov.bc.ca/cas/pdfs/2012-Progress-to-Targets.pdf, accessed 28 July 2014.

27. Government of BC (2014), www.env.gov.bc.ca/cas/pdfs/2014-Progress-to-Targets.pdf, accessed 28 July 2014.

28. Pembina Institute (2012), 'British Columbians Willing to Pay More Carbon Tax: Poll', www.pembina.org/media-release/2377, accessed 28 July 2014.

29. Pembina Institute (2012), www.pembina.org/reports/carbon-tax-polling-results.pdf, accessed 28 July 2014.

30. Coyne, A. (2009), www.macleans.ca/news/canada/a-new-coalition-a-different-politics/, accessed 28 July 2014.

31. Ekins, Paul (2012), Submission to the British Columbia Government's Carbon Tax Review, August 2012. 